\title{
A Shift in The Review Model of Local Regulation
}

\author{
Ima Mayasari \\ Faculty of Administrative Science Universitas Indonesia \\ Kampus Baru UI Depok, 16424 \\ E-mail: imamayasari@ui.ac.id
}

\begin{abstract}
After the Constitutional Court/Mahkamah Konstitusi ("MK") Decision in the case of Judicial Review of Law Number 23 of 2014 concerning Local Government against The 1945 Constitution of the Republic of Indonesia, which was pronounced in MK Plenary Session on Wednesday, 5 April 2017, the authority of the executive i.e. the Governor to revoke a Regency/Municipality Regulation and Regent/Mayor Regulation (Perda/Perkada) was declared as against The 1945 Constitution of the Republic of Indonesia (UUD NRI 1945). MK stated that the phrase "Regency/Municipality Regulation and" in Article 251 paragraph (2) and paragraph (4), the phrase "Regency/Municipality Regulation and/or" in Article 251 paragraph (3), and the phrase "A Deputy Governor of the Central Government does not invalidate legislation Regency/City and" and the phrase "Regency/Municipality Regulation or" in Article 251 paragraph (8) Law Number 23 of 2014 are in violation of UUD NRI 1945 and have no binding legal power. Therefore, the President - through the Minister and the Governor-no longer has the authority to revoke Perda/Perkada. The power that holds full authority is the judiciary through the judicial review mechanism. This research aims to explain the review model of Perda/Perkada, to identify the mechanism of Perda/Perkada revocation based on Law Number 23 of 2014, and to identify the legal implication of MK Decision in the case of Review of Law Number 23 of 2014 on UUD NRI 1945. The research methodology used is qualitative data collection method in the form of literature research. Research result suggests that MK incorrectly made the Decision that abolishes the executive review of Perda/Perkada, given that Law Number 23 of 2014 which grants the authority to the Presidentthrough the Minister and the Governor - to revoke a Perda/Perkada is not meant to replace or take over the judicial review authority from the Supreme Court ("MA") as a justice or judicial authority institution, therefore the abolition of the executive review regulation is feared to result in lack of legal certainty in the implementation of a controversial Perda/Perkada.
\end{abstract}

Keywords—Local Regulation, Judicial Review, Executive Review.

\section{INTRODUCTION}

After MK Decision Number 137/PUU-XIII/2015 in the case of Judicial Review of Law Number 23 of 2014 against UUD NRI 1945, which was pronounced in MK Plenary Session on Wednesday, 5 April 2017, there was a shift in the review model of Local Regulation ("Perda/Perkada") from executive review to judicial review. The executive review as in Article 251 of Law No. 23 of 2014 essentially regulates that "regulations regents/mayors are contrary to the provisions of the legislation are higher, the public interests, and/or decency is revoked by the Minister of Home Affairs". Meanwhile, Perda/Perkada that is against higher laws, public interests, and/or decency is revoked by the Governor as a Representative of the Central Government.

The revocation of Province Regulation and Governor Regulation is decided by a Minister of Home Affairs Decision and the revocation of Regency or City Regulation and Regent or Mayor Regulation is decided by a Governor Decision as a Representative of the Central Government. The request for judicial review to $\mathrm{MK}$ in relation with executive review based on Article 251 paragraph (2), paragraph (3), paragraph (4), and paragraph (8) of Law No. 23 of 2014 specifically the phrase, "the revocation of Regency/City Regulations and Regent/Mayor Regulations refererred to Article 251 (2) shall be determined by the decision of the Governor as a representative of The Central Government" is against Article 18 paragraph (6) of UUD NRI 1945, which states, "The regional authorities shall have the authority to adopt local regulations and other regulations to implement autonomy and the duty of assistance", and Article 28D paragraph (1) UUD NRI 1945, which states, "Every person shall have the right of recognition, guarantees, protection and certainty before a just law, and of equal treatment before the law", and Article 24A paragraph (1) UUD NRI 1945 concerning constitutional authority of MA, "The Supreme Court shall have the authority to hear a trial at the highest (cassation) level, to review ordinances and regulations made under any law against such law, and shall possess other authorities as provided by law".

The mechanism of Perda/Perkada revocation regulated by Law No. 23 of 2014 through the Governor and objection filing to the Minister, is considered by the Applicant as against Article 31 of Law No. 5 of 2004 concerning Amendment to Law No. 14 of 1985 concerning MA in conjunction with Law No. 3 of 2009 concerning Second Amendment to Law No. 14 of 1985 and Law No. 12 of 2011 concerning Formulation of Law that states that the validity of regulations under a law can be reviewed by MA if it is against the law. Therefore, according to the Applicant, there has been a legal uncertainty, which violates Article 28D paragraph (1) of UUD NRI 1945. Provincial Government's right to make a law is a right granted directly by the Constitution through Article 18 paragraph (6) of UUD NRI 1945. Therefore, such a right should be revocable only by a State Institution whose authority is granted also by the Constitution, namely MA as the holder and executor of judicial power as set out in Article 24A paragraph (1) of UUD NRI 1945, which essentially states that MA is granted 
the authority to adjudicate at the court of cassation and examine laws under a law against a law. Perda and Perkada is a type of law which is hierarchically under a law, therefore, according to the Applicant, based on the Constitution, only MA has the right to revoke or adjudicate the request for Perda revocation, not other institutions.

An executive review has been conducted by the Government via the Ministry of Home Affairs. Based on the Instruction of the Minister of Home Affairs of the Republic of Indonesia No. 582/476/SJ dated 16 February 2016 concerning Revocation of/Amendment to Perda, Perkada, and Local Government Decision that Obstruct Investment Bureaucracy and Licensing, the Minister of Home Affairs in executing the instruction of the President of the Republic of Indonesia to act on the proliferation of Perda, Perkada, and Local Government Decision that violate higher laws, obstruct investment bureaucracy and licensing, and impose various charges especially to business.

Furthermore, on 21 June 2016, the Ministry of Home Affairs of the Republic of Indonesia has officially uploaded a list containing 3,143 Perda/Perkada that have been revoked or revised, which consists of 1,765 Perda/Perkada that have been revoked/revised by the Minister of Home Affairs of the Republic of Indonesia, and 1,267 Perda/Perkada that have been revoked/revised by the Governor. According to the Minister of Home Affairs, the purpose of the Perda/Perkada revocation/revision is to improve the nation's competitiveness in this era. Those Perda are considered as hampering provincial economic growth and lengthening bureaucracy channel, and obstructing investment and ease of doing business.

However, in conducting the executive review, as a follow-up action the Government implements Article 251 of Law No. 23 of 2014, which in case Number 137/PUUXIII/2015 in MK the Article 251 paragraph (2), paragraph (3), paragraph (4), and paragraph (8), specifically the phrase, "the revocation of Regency/Municipality Regulation and Regent/Mayor Regulation as set out in paragraph (2) is decided by a Governor Decision as a Representative of the Central Government", is regarded by the Applicant as inconstitutional.

Based on the above explanation, the researcher formulates several problems that become the focus of the research, namely: first, the review model of Perda/Perkada that is considered as against higher laws; second, the Perda/Perkada revocation mechanism based on Law No. 23 of 2014; and third, legal implication of Number 137/PUUXIII/2015 in the case of Review of Law No. 23 of 2014 against UUD NRI 1945.

The objectives of the research include: first, explain the review model of Perda/Perkada that is considered as against higher laws; second, identify the Perda/Perkada revocation mechanism based on Law No. 23 of 2014; and third, identify the legal implication on MK Decision in the case of Review of Law No. 23 of 2014 against UUD NRI 1945.
This research uses qualitative data collection method, namely literature research, in which all data required in this research, which is available in written form in various forms of documentation, such as books, research report, journals, essays, newspapers, and brochures.

\section{DISCUSSION}

\section{A. Theoretical Study of Law Review Model}

Law review model is proposed by several experts. According to Asshidiqie (2009, p. 590), law review in terms of subject consists of: (1) review by executive institution, which is referred to as executive review; (2) review by legislature institution, which is referred to as legislative review; and (3) review by judiciary institution, which is referred to as judicial review. Meanwhile, according to Mahfud, there are four types of law review in Indonesia, namely: (1) constitutional review; (2) judicial review; (3) legislative review (political review); and (4) executive review (Mahfud, 2009, p. 64). The explanation of the types of law review is as follows:

Constitutional review is a review of law against UUD NRI 1945 performed by the MK as mandated by Article 24C paragraph (1) of UUD NRI 1945. MK has the authority to review the constitutionality of a legislative law or legislation.

A judicial review is an examination of regulations made under any law against such law, which is performed by MA based on Article 24A paragraph (1) UUD NRI Tahun 1945, as related to Article 7 Law No. 12 of 2011, MA has the authority to review: Government Regulation, Presidential Regulation, Provincial Regulation, and Regency/Municipality Regulation. In order to exercise its authority to review a law, MA issued the MK Regulation Number 1 of 2004 concerning Right to Material Review. According to Article 1 point (1) of MA Regulation No. 1 of 2004, the right to material review the right of MA to assess the material of a law under a law against higher laws. In the event that MA is of the opinion that the objection is valid since the law is against a legislation or higher laws, MA grants the objection. MA will make a decision stating that the controversial law is invalid and does not apply for the public, and ordered the relevant institution to revoke it immediately. In the event that MA is of the opinion that the objection is groundless, MA will reject the objection.

Legislative review is a material review performed by a legislative institution against a law. In Indonesia, legislative review is performed by DPR against a Government Regulation in Lieu of Law/Peraturan Pemerintah Pengganti Undang-Undang (PERPPU). A legislative review is also a review of or amendment to a Law or Perda by the legislature (DPR/DPRD and Government/Local Government) according to the level because the content is against the law or the underlying philosophy. This is true for a Perda that has been revoked by MA or the Central Government 
through a Presidential regulation.

Executive review is a review of legislation material performed by an executive institution. In Indonesia, the legislation reviewed is not a law (Undang-undang) but a regulation under a law (Undang-undang). One example is a review of a Provincial Regulation performed by the Central Government. As previously explained, there are various forms of review and not all of them can be performed on all laws. A review cannot be performed without legitimate authorization by law.

Before a legislation is enacted in a provincial government, it must be examined and/or approved first by an institution which has higher structural position in the hierarchy than the institution that makes the legislation. Emphasis is given as a part of preventive element in a review, because the purpose is to maintain the utility (doelmatigheid) and legality (rechtmatigheid) of the legislation before it is validated and publicly enacted. An executive review is performed on a legislation in a provincial government after it is passed and enacted but may be reviewed and revoked by an institution which has higher structural position in the hierarchy than the institution that makes the legislation. It is called a-posteriori review if it is done after a regulation or decision is made or after a government action or measure is taken. In this case the emphasis is on correcting and recovering from the mistake made by the government or institution.

This executive review model is similar in characteristics to an administrative measure (internal review). In brief, an administrative procedure (internal review) with its many variations is meant to: give an opportunity to the official that made the decision to review the legality and utility aspects of the decision or disapproval; give an opportunity to the objecting party to use non litigation review means that is not expensive and not time consuming; and give the Administration Judiciary the freedom to produce a decision that does not burden the government.

Law No. 23 of 2014 regulates the Revocation of Perda and Perkada in CHAPTER IX on Perda and Perkada, Section Three (Revocation of Perda and Perkada) Article 249 to Article 251, reinforces the executive's position in carrying out the duties of monitoring Perda and Perkada. Provincial Regulation and Governor Regulation that violates higher laws, public interests, and/or decency shall be revoked by the Minister. Regency/Municipality Regulation and Regent/Mayor Regulation that violates higher laws, public interests, and/or decency shall be revoked by the Governor as a Representative of the Central Government. Revocation of Provincial Regulationand Governor Regulation is decided by a Minister Decision and revocation of Regency/Municipality Regulation and Regent/Mayor Regulation is decided by a Governor Decision as a Representative of the Central Government.

No later than 7 (seven) days after the revocation Decision of Perda/Perkada either in the form of Minister
Decision or Governor Decision, the local government head must stop the Perda/Perkada execution and then DPRD together with the local government head shall revoke the respective Perda/Perkada. In the event that the administrator of the Provincial Government cannot accept the Provincial Regulation revocation decision and the Governor cannot accept the Governor Decision revocation decision for a reason that is in accordance with the laws, the Governor may file an objection to the President no later than 14 (fourteen) days after the Perda or Governor Regulation revocation decision is accepted. Meanwhile, In the event that the administrator of the Regency/Municipality Government cannot accept the Regency/Municipality Regulation revocation decision and the Regent/Mayor cannot accept the Regent/Mayor Regulation revocation decision for a reason that is in accordance with the laws, the Regent/Mayor may file an objection to the Minister no later than 14 (fourteen) days after the Regency/Municipality Regulation or the Regent/Mayor Regulation revocation decision is accepted.

Besides regulating the Perda Revocation Mechanism, Article 252 also regulates the imposition of sanctions. The administrator of the Provincial or Regency/Municipality Government that continues to execute Perda regulating local tax and/or local retribution that has been revoked by the Minister or the Governor as a Representative of the Central Government is subject to postponement or reduction of the respective local government's General Allocation (DAU) and/or Sharing (DBH).

\section{B. Problems in Self-Legislation (Zelfwetgeving)}

The practice of self-legislation (zelfwetgeving) at Provincial Regulation (Perda) level, remains problematic. Perda that has been enacted both by the provincial government and regency/municipality government is still ridden with problems, namely Perda that is not designed or developed according to the principles of legislative drafting. Perda is only drafted by local executive or local legislature without involving the people who essentially are knowledgeable of local conditions. Neglected economic or investment principles has caused excessive tax increase, resulting in high cost economy. Problems in local tax or local retribution often burden the people, leading to high cost economy.

The result of recapitulation of problematic Perda conducted by Provincial Autonomy Implementation Monitoring Committee (KPPOD) in 2003 shows that provincial governments often try to maximize locally generated income by assuming that in the majority of provincial governments the locally generated income/PAD only contributes $10-30 \%$ to local APBD, prompting shortsighted actions to increase PAD. Three types of problems are (1) juridical/technical problems, (2) substance problems, and (3) principle problems. Juridical/technical problems include juridical relevance-whether the juridical 
foundation used is relevant with Perda substance; up to date juridical reference-whether the juridical reference used is still applicable; and formal juridical completeness - whether there is formal juridical completeness. Perda substance problems are related to disconnection between Perda objective and content; clarity of Perda object; clarity of Perda subject; whether or not the clarity of taxable's and/or provincial government's rights and obligations exists or regulated; clarity of procedure and bureaucracy-service time and rate standards and/or time limits; suitability of tax philosophy and principle (tax, retribution, retribution category). Meanwhile, principle problems include violation of the principle of integrity of national economic territoryobstructing goods and services distribution traffic both interterritory tariff and non-tariff/violation of the principle of free internal trade, causing unhealthy business competition (monopoly, oligopoly, mandatory partnership, etc); bringing negative impact to the economy-high cost economy, double taxation, heavy burden on the people or the business world); obstructing or reducing people's access (violation of the principle of justice and violation of public interest); and violation of governmental authority.

\section{Shift in Perda Review Model from Executive Review to Judicial Review after MK Decision}

The focus of the study of Perda/Perkada review model that is considered as violating higher laws and the legal implication on Number 137/PUU-XIII/2015 can be explained as follows:

According to legislation theory, examination by an executive institution (executive review) is not something new. In fact, it is a necessity in many countries. The function of executive review is to ensure that the legislation drafting authorized to the lower executive does not violate higher legislations, including those drafted by the executive that has the authority to conduct the review. Nevertheless, executive review is just another legislation review instrument besides judicial review. Executive review cannot replace judicial review, and conversely, judicial review may negate evecutive review. In MK Decision Number 137/PUU-XIII/2015, a case of Review of Law Number 23 of 2014, MK is of the opinion that Article 251 paragraph (2) and paragraph (3) violates UUD NRI 1945.

According to MK, Article 251 paragraph (2) and paragraph (3) of Law Number 23 of 2014 that authorizes the Minister and Governor as a Representative of the Central Government to revoke Regency/Municipality Regulation that violates higher legislations, defies the logic and structure of the legal state of Indonesia as mandated by Article 1 paragraph (3) UUD 1945 and also negates the role and function of MA as an institution that has the authority to review the legislation under legislation in casu Regency/Municipality Regulation as stated in Article 24A paragraph (1) UUD 1945. Similarly, with regard to public interests and/or decency which are also used as benchmarks in revoking a Perda as set out in Article 251 paragraph (2) and paragraph (3) of Law Number 23 of 2014, MK is also of the opinion that the application of those benchmarks is the domain of MA, besides higher laws, and since it is regulated by law, it can also be used as a testing stone by MA in adjudicating a Perda review.

Furthermore, MK is of the opinion that revocation of Regency/Municipality Regulation through Governor Decision as a Representative of the Central Government as set out in Article 251 paragraph (4) of Local Government Law is not consistent with the legislation regime adhered to by Indonesia. Article 7 paragraph (1) and Article 8 of Law Number 12 of 2011 does not recognize Governor Decision as a type and hierarchy of legislation. Therefore, Governor Decision is not a part of legislation and cannot be used as a legal product to revoke a Regency/Municipality Regulation. In other words, MK has identified a mistake, namely Regency/Municipality Regulation as a legal product that takes the form of a regulation (regeling) can be revoked by a Governor Decision as a legal product that takes the form of a a decision (beschikking). Besides that, the legal product of Perda revocation in executive scope by a legal product of Governor Decision as set out in Article 251 paragraph (4) of Local Government Law has the potential to create a duality of court decision if the authority to review or revoke a Perda is present in the executive and judiciary powers. The potential duality of court decision between Administrative Court decision and Perda review decision by MA has the same case substance, but the difference in legal product will create legal uncertainty, whereas legal certainty is the right of every person which is guaranteed and protected by Article 28D paragraph (1) of UUD NRI 1945. Therefore, for the sake of legal certainty and compliance with UUD 1945, MK is of the opinion that Perda review or revocation is the constitutional authority domain of MA.

Based on the above explanation, Article 251 paragraph (2), paragraph (3), and paragraph (4) of Law No. 23 of 2014 regulating Perda violates UUD NRI 1945. Similarly, Article 251 paragraph (8) of Local Government Law regulating the mechanism of filing objection to revocation of Perda as regulated in Article 251 paragraph (2), paragraph (3), and paragraph (4) of Law No. 23 of 2014 has been declared as violating UUD NRI 1945 by MK, therefore Article 251 paragraph (8) of Law No. 23 of 2014 has lost its relevance, therefore Article 251 paragraph (8) of Law No. 23 of 2014 regulating Preda must also be declared as violating UUD NRI 1945.

Perkada according to Article 1 point 26 of Law No. 23 of 2014 is Governor Regulation and Regent/Mayor Regulation. Next, Article 246 paragraph (1) of Law No. 23 of 2014 states, "The Governor has the authority to establish Perkada in order to execute Perda or by the power of legislation." Unlike Regency/Municipality Regulation which is formulated by DPRD with the approval of the Regent/Mayor (vide Article 1 point 8 of Law No. 12 of 2011), Regent/Mayor Regulation is formulated by the Regent/Mayor without the involvement of DPRD. Perkada 
according to Article 8 paragraph (2) of Law No. 12 of 2011 is a type of legislation, since it is formulated only by the Governor as a bestuur unit in order to implement Perda and mandatory government affairs as regulated in Law No. 23 of 2014. Therefore, according to MK, in the framework of a unitary state, the Central Government as a higher bestuur unit has the authority to revoke Perkada.

Revocation and mechanism of filing objection to Perkada revocation in Law No. 23 of 2014 is a part of the monitoring mechanism on the Provincial Government by the President or Minister and Governor as a Representative of the Central Government or in other words it is a form of monitoring, not legislation review, in bestuur environment by a higher bestuur unit on a lower bestuur unit. In the previous Provincial Government Laws, both Law No. 22 of 1999 and Law No. 32 of 2004, there is no provision that regulates Perkada revocation and mechanism of filing objection to its revocation.

Two terminologies are used to refer to Perkada, namely Governor Regulation/Peraturan Kepala Daerah and/or Governor Decision/Keputusan Kepala Daerah (vide Article 146 of Law No. 32 of 2004) or simply Governor Decision/Keputusan Kepala Daerah (vide Article 72 of Law No. 22 of 1999). Later on, Law No. 23 of 2014 regulates Perkada revocation and the mechanism of filing objection to its revocation together with Perda. Because of this, according to MK, lawmakers place Perkada as a Governor Decision or also referred to as State Administration Decision, even though the legal product is a Regent/Mayor Regulation, which means monitoring mechanism by the government above it is possible and it does not violate UUD NRI 1945. The control mechanism by the government above it belongs to the scope of state administration function (bestuursfunctie).

Based on the above explanation, the regulation of Perkada revocation in casu Regent/Mayor Regulation and the mechanism of filing objection to its revocation as regulated in Article 251 paragraph (2), paragraph (3), paragraph (4), and paragraph (8) of Law No. 23 of 2014 does not violate UUD NRI 1945 according to MK.

\section{CONCLUSION}

Based on the above explanation, the following conclusions can be drawn:

1. The act of "revocation" should be differentiated from "judicial review". Judicial review is a part of the authority of the judiciary or judicial power that can be appealed by those who feel disadvantaged by the enactment of a legislation, in this case the Provincial Regulation, because they said legislation violates a higher law. Meanwhile, "revocation" is a part of government power (executive)-executive review. Therefore, Law No. 23 of 2014 has correctly bestowed the authority to the President (via the Minister and the Governor) to revoke Perda and Perkada. This authority is not meant to substitute or replace the judicial review authority held by the justice or judiciary power, therefore Law No. 23 of 2014 does not obstruct or eliminate the right of those who feel disadvantaged by the enactment of a Perda and Perkada to appeal for a judicial review.

2. After MK Decision Number 137/PUU-XIII/2015 in the case of Review of Law Number 23 of 2014 against UUD NRI 1945, which was pronounced in MK Plenary Session on Wednesday, 5 April 2017, there was a shift in the review model of Provincial Regulation (Perda) from executive review to judicial review, with MK Decision that states that the phrase "Regency/Municipality Regulation and" in Article 251 paragraph (2) and paragraph (4), the phrase "Regency/Municipality Regulation and/or" in Article 251 paragraph (3), and the phrase "the administrator of Regency/Municipality Government cannot accept the Regency/Municipality Regulation revocation decision and" and the phrase "Regency/Municipality Regulation or" in Article 251 paragraph (8) of Law Number 23 of 2014 is a violation of UUD NRI 1945 and has no binding legal power.

3. The legal implication of the MK Decision Number 137/PUU-XIII/2015 is that any legal action taken against a problematic Perda/Perkada will be a violation of a higher legislation, namely Judicial Review to MA. Therefore, the Minister of Home Affairs does not immediately revoke a problematic Perda/Perkada, but first appeals for a Judicial Review to MA.

\section{REFERENCES}

(1) Jazim Hamidi., 2012, Optik Hukum Peraturan Daerah Bermasalah, Jakarta: Laks Bang Presindo.

(2) Jimly Asshidiqie., 2007, Pokok-Pokok Hukum Tata Negara Indonesia Pasca Reformasi, Jakarta: PT Bhuana Ilmu Populer.

(3) Moh. Mahfud, MD., 2009, Konstitusi dan Hukum dalam Kontroversi Isu, Jakarta: Rajawali Pers.

(4) Law of the Republic of Indonesia Number 23 of 2014 concerning Provincial Government, State Gazette of the Republic of Indonesia of 2014 Number 244, Supplement to the State Gazette of the Republic of Indonesia Number 5587.

(5) Instruction of the Minister of Home Affairs of the Republic of Indonesia Number 582/476/SJ dated 16 February 2016 concerning Revocation of/Amendment to Provincial Regulation, Governor Regulation, and Governor Decision that Obstructs Investment Bureaucracy and Licensing.

(6) Constitutional Court/Mahkamah Konstitusi (MK) Decision Numbet 137/PUU-XIII/2015 in the case of Review of Law Number 23 of 2014 concerning Provincial Government against the 1945 Indonesian Constitution (Undang-Undang Dasar Negara Republik Indonesia Tahun 1945).

(7) Statistics of Problematic Perda Found in KPPOD Study in 2003, http://www.kppod.org. 